\title{
ASSIMILATION OF SEA SURFACE HEIGHT ANOMALIES INTO HYCOM WITH AN OPTIMAL INTERPOLATION SCHEME OVER THE ATLANTIC OCEAN METAREA V
}

\author{
Clemente Augusto Souza Tanajura1,2, Filipe Bitencourt Costa², Renato Ramos da Silva2,3, \\ Giovanni Abdelnur Ruggiero ${ }^{4}$ and Victor Bastos Daher ${ }^{5}$
}

\begin{abstract}
Along-track sea surface height anomaly (SSHA) data from the Jason-1 and Jason-2 satellites were assimilated into the ocean model HYCOM from July 1, 2009 until December 31, 2009. A new and simple approach to overcome the bias between the model and observed SSHA was proposed. It focuses on the meso-scale differences between the data and the model along each satellite track. An optimal interpolation method and the Cooper \& Haines (1996) scheme (C\&H) were employed to produce a SSHA analysis field and to adjust model layer thicknesses over the Atlantic METAREA V. The corrected model state was used as initial condition for the next assimilation cycle. SSHA data with a 7-day window were assimilated in 3-day intervals centered in the SSHA data window and the C\&H scheme was applied taking the SSHA analysis. A control run without assimilation was also performed. The results showed that the model SSHA was completely reorganized by the end of the experiment. The modifications of SSHA were compared to the American Navy HYCOM+NCODA system and AVISO data. Maximum error was reduced from $0.7 \mathrm{~m}$ to $0.2 \mathrm{~m}$ by assimilation. Comparisons were also made with the Argo temperature and salinity vertical profiles. Improvements in the currents and volume transport were also produced by assimilation. The impact in temperature was in general positive, but there was no substantial modification in salinity.
\end{abstract}

Keywords: ocean data assimilation, Jason-1 and Jason-2 satellites, Argo.

RESUMO. Dados de anomalia da altura da superfície do mar (AASM) dos satellites Jason-1 e Jason-2 foram assimilados no modelo oceânico HYCOM de 1 de julho de 2009 a 31 de dezembro de 2009. Um nova e simples abordagem foi proposta para superar o viés entre os dados observados de AASM e 0 campo do modelo. Ela enfoca as diferenças entre o modelo e as observações na mesoescala ao longo de cada trilha dos satélites. Um método de interpolação estatística e 0 esquema de Cooper \& Haines (1996) (C\&H) foram empregados para produzir um campo de análise de AASM e ajustes nas espessuras das camadas do modelo sobre a METAREA V do Atlântico. 0 estado corrigido do modelo foi usado como condição inicial para o próximo ciclo de assimilação. Dados de AASM em uma janela de 7 dias foram assimilados a cada 3 dias em data centrada na janela de dados e o método de C\&H foi aplicado com a análise de AASM. Os resultados mostraram que a AASM do modelo foi completamente reorganizada no final do experimento. As modificações de AASM foram comparadas com análises globais do sistema Americano HYCOM+NCODA e com dados do AVISO. Erros máximos foram reduzidos de 0,7 m para 0,2 $\mathrm{m}$ com a assimilação. Comparações foram também feitas com perfis verticais de temperatura e salinidade do Argo. Melhorias nas correntes e no transporte de volume foram produzidas em relação à rodada de controle. 0 impacto na temperatura foi em geral positivo, mas não houve modificação substancial na salinidade.

Palavras-chave: assimilação de dados oceanográficos, satélites Jason-1 e Jason-2, Argo.

\footnotetext{
1 Departamento de Física da Terra e do Meio Ambiente, Instituto de Física, Universidade Federal da Bahia (UFBA), Campus de Ondina, Travessa Barão de Jeremoabo, s/n, 40170-280 Salvador, BA, Brazil. Phone: +55(71) 3283-6685; Fax: +55(71) 3283-8501 - E-mail: cast@ufba.br

${ }^{2}$ Rede de Modelagem e Observação Oceanográfica (REM0), Centro de Pesquisa em Geofísica e Geologia, Universidade Federal da Bahia (CPGG/UFBA), Instituto de Geociências, Rua Barão de Jeremoabo, s/n, 40170-290 Salvador, BA, Brasil. Phone: +55(71) 3283-8531; Fax: +55(71) 3283-8501 - E-mail: cast@ufba.br

${ }^{3}$ Departamento de Física, Universidade Federal de Santa Catarina (UFSC), Bairro da Trindade, Caixa Postal 476, 88040-970 Florianópolis, SC, Brasil. Phone: $+55(48)$ 3721-6831 - E-mail: renato@fsc.ufsc.br

${ }^{4}$ Instituto de Oceanografia, Universidade Federal do Rio Grande (FURG), Caixa Postal 474, 96201-900 Campus Carreiros, RS, Brasil. Phone: +55(53) 3233-6710; Fax: +55(43) 3233-6601-E-mail: ocrug@gmail.com.

${ }^{5}$ Departamento de Meteorologia, Instituto de Geociências, Universidade Federal do Rio de Janeiro (UFRJ), Rua Athos da Silveira Ramos, 274, Bloco G1, Cidade Universitária, Ilha do Fundão, 21941-916 Rio de Janeiro RJ, Brasil. Phone-Fax: +55(21) 2598-9471 - E-mail: victor@Ima.ufrj.br
} 


\section{INTRODUCTION}

Developments in ocean observation during the past two decades have allowed the implementation of in situ global and regional operational ocean monitoring systems. The Tropical Ocean Global Atmosphere Program/Tropical Atmosphere Ocean Project (TOGA/ TAO), the Prediction and Research Moored Array in the Tropical Atlantic (PIRATA), the Research Moored Array for AfricanAsian-Australian Monsoon Analysis and Prediction (RAMA) and the Argo system of floating profilers are among the successful initiatives in this direction. However, remote sensed data of sea surface temperature (SST) and sea surface height (SSH) are also key-components of the ocean observing system because data from in situ systems are still relatively coarse to capture the ocean meso-scale variability. Important contribution came from the Global Climate Observing System (GCOS) Implementation Plan (GCOS-92, 2004) not only to integrate and composite satellite information with in situ data, but also to build data management and analysis tools.

In order to make the best use of the observational system, data assimilation methods have been realized with several ocean circuIation models. Data assimilation methods combine observational data with model results to produce the so-called objective analysis with smaller errors than the model results (Daley, 1991; Kalnay, 2003). The Global Ocean Data Assimilation Experiment (GODAE) and its continuation, the GODAE OceanView, have demonstrated that to constrain the ocean state and produce accurate representation of the ocean three-dimensional state and circulation, surface data sampled in high resolution should be assimilated in conjunction with the coarser in situ data (Oke et al., 2009; Cummings et al., 2009). The different data are actually complementary and not redundant. Also, different regions have different sensitivity to specific data.

The capacity of assimilating all available data into ocean models and the existence of reliable operational observational systems permitted the operational ocean weather forecasting systems (OOFSs) to become a reality. Several systems are running today in different countries to provide updated analysis, nowcasts and forecasts with prognostics from days to a month in specific regions or over the global ocean. Among these systems, there are the American HYCOM+NCODA, the French Mercator Océan and the Norwegian TOPAZ (Dombrowsky et al., 2009; Cummings et al., 2009). They are under the framework of GODAE OceanView along with operational ocean weather forecasting systems from Australia, Canada, China, Italy, Japan, United Kingdom and the United States, which contributes with more than one system.
For instance, HYCOM+NCODA is based on a $1 / 12^{\circ}$ global Hybrid Coordinate Ocean Model (HYCOM) initialized by the US Navy Coupled Ocean Data Assimilation (NCODA) system, which employs a multivariate optimal interpolation scheme to assimilate altimetry data, SST and vertical profiles of temperature and salinity from moored buoys and from the Argo floaters. HYCOM+ NCODA is hosted by the US Naval Oceanographic Office (NAVOCEANO) in collaboration with the HYCOM Consortium and it produces daily five-day hindcast with assimilation and a five-day forecast.

The present work investigates the impact of assimilation of along-track SSH anomalies (SSHA) retrieved from remotely sensed data into the ocean circulation model HYCOM with focus on the South Atlantic. The data assimilation method employed was the optimal interpolation (OI) scheme, actually a statistical interpolation scheme since the model error covariance matrix was only an approximation of true statistics. The SSHA analysis is used along with the Cooper \& Haines (1996) scheme (C\&H) to pass information from the surface to the subsurface by altering the model layer thicknesses. This work is a crucial step towards the construction of a full multivariate ocean data assimilation system, as the ones implemented in HYCOM+NCODA and several other operational systems under GODAE OceanView (www.godae-oceanview.org). It presents an original and alternative approach to treat the commonly found bias that exists between the model SSHA and the observed SSHA. This work is an effort of the Oceanographic Modeling and Observation Research Network (REMO) towards the construction of a high quality operational ocean forecasting system (www.rederemo.org) (Tanajura \& Belyaev, 2009).

\section{METHODOLOGY \\ Altimetry Data}

The Geophysical Data Record (GDR) SSHA from Jason-1 and Jason-2 satellites distributed by Archivage, Validation et Interprétation des données des Satellites Océanographiques (AVISO) are used in this work. AVISO distributes several versions of the altimeters data directed for different purposes but the GDR has the best accuracy and level of validation. All instrumental, geophysical and environmental corrections are included in this data. However, GDR has lower accuracy near the coast due to inaccurate tidal corrections. The errors have the same order of magnitude of tides $(10 \mathrm{~cm}$ to $1 \mathrm{~m})$. The coastal region is often defined as shallower than $1000 \mathrm{~m}$ depth as recommended by OSTM/Jason-1 and 2 Products Handbook. Therefore, in the present work data in this region are excluded. 


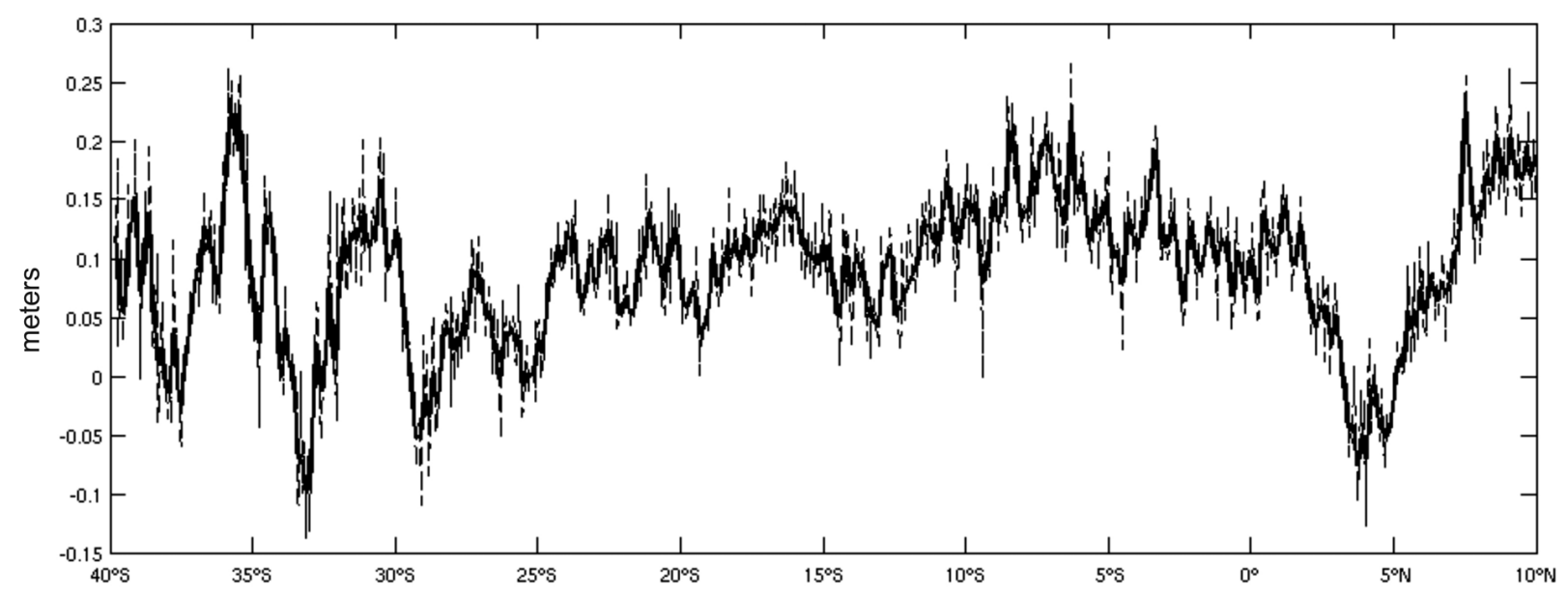

Figure 1 - Raw along-track SSHA data (dashed line) and filtered SSHA data (thick line) for track 74 of cycle 276 from Jason-1 over the South Atlantic on July 1, 2009.

The resolution of the along-track data is approximately $6 \mathrm{~km}$ and it is very noisy. A 7-point Gaussian convolution filter was applied to reduce the noise and to exclude wavelengths smaller than $40 \mathrm{~km}$. The effect of filtering can be observed in Figure 1 for one track along the South Atlantic on July 1, 2009. The filter shape function was chosen to minimize the formation of side lobes in the spectrum. Each track is filtered separately considering the distance between measurements. If there are gaps in data, data is eliminated in the regions in which the number of consecutive measurements is less than the length of the filter (7 points or $42 \mathrm{~km}$ ), since it is not possible to smooth these data. After filtering the data, the area of interest is selected and all tracks on the same day are concatenated.

The measurement of SSHA performed by altimeter is obtained punctually along the satellite track. The altimeters used in the present experiment take approximately 10 days to cover the entire globe and the number of measurements in the area of interest in one day may be insufficient to produce significant impact in the SSH background. Therefore, a strategy was applied to use more than one day of data to increase the number of measurements and consequently cause greater impact in the analysis. A seven day window data was considered here for assimilation. An example of the coverage by tracks available in a 1-, 3-, 5- and 7-day window can be seen in Figure 2.

\section{The ocean model}

HYCOM solves five prognostic equations for the ocean circulation: two for the horizontal motion, the continuity equation, and two equations for the thermodynamic conservation that can be salinity and potential temperature (Bleck, 2002, 2006; Chassignet et al., 2009). The model is structured with a hybrid vertical coordinate system to solve the prognostic equations according to the genuine work by Bleck \& Boudra (1981) and Bleck \& Benjamin (1993). It uses isopycnal coordinates for the open stratified ocean, which reverts to terrain-following coordinates in shallow coastal regions, and $z$-level coordinates in the mixed layer and over unstratified ocean regions. The coordinate system choice is adjusted to the best option according to the ocean characteristics. The model version 2.1.14 was used in the present experiments.

HYCOM was configured with horizontal resolution of $1 / 12^{\circ}$ with 601 by 733 grid points in the zonal and meridional directions, respectively, for the South Atlantic over the region $56^{\circ} \mathrm{S}$ $10^{\circ} \mathrm{N}, 60^{\circ} \mathrm{W}-20^{\circ} \mathrm{W}$. This model was integrated nested in another HYCOM integration with horizontal resolution of $1 / 4^{\circ}$ HYCOM over the region $78^{\circ} \mathrm{S}-55^{\circ} \mathrm{N}, 100^{\circ} \mathrm{W}-20^{\circ} \mathrm{E}$. The latter covers the Caribbean Sea and the major part of the Atlantic Ocean. The corresponding area of the South Pacific is excluded. The model in both domains was configured with 21 vertical layers, from which 18 are hybrid and the top 3 are fixed as $z$-coordinate layers with minimum thickness of $3 \mathrm{~m}$. In coastal waters, there are up to 12 sigma levels and the coastline is at $10 \mathrm{~m}$ isobath. In the coarse grid domain, the north and south boundaries for temperature, salinity and pressure are linearly relaxed toward the World Ocean Atlas (WOA) climatological data [http://www.nodc.noaa.gov/OC5/WOD05/pr_wod05.html]. Constant barotropic volume fluxes were imposed in the coarser grid: zero flux in the north; eastward flux of $110 \mathrm{~Sv}$ in the Drake Passage; westward flux of $10 \mathrm{~Sv}$ in 12 grid points south of South Africa along $20^{\circ} \mathrm{E}$; and eastward flux of $120 \mathrm{~Sv}$ from the latter region until Antarctica. Relaxation to climatology was imposed on the sea surface temperature and on the sea surface salinity up to 

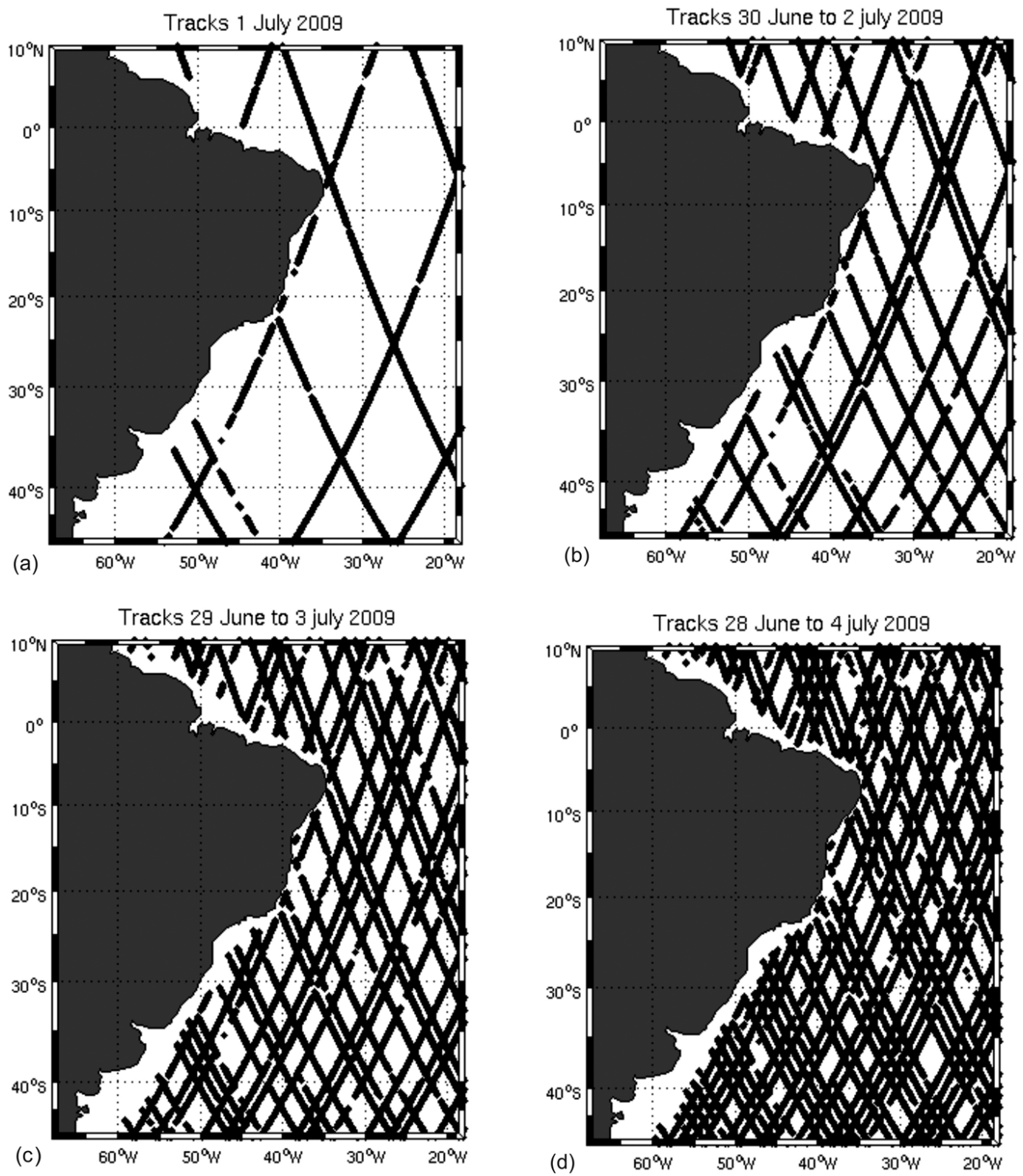

Figure 2 - Tracks of SSHA data for: (a) 1 July 2009; (b) 30 June - 2 July 2009; (c) 29 June - 3 July 2009; (d) 28 June - 4 July 2009.

$19 \mathrm{~m}$ depth. The model was run with the Message Passing Interface (MPI) system of parallelization and the region of interest was partitioned in 64 processors.

The model in the coarser grid was initialized with the World Ocean Atlas temperature and salinity fields at rest. It was first integrated for 40 years with atmospheric forcing from the Comprehensive Ocean-Atmosphere Data Set (COADS) climatological monthly mean fields (available at http://icoads.noaa.gov) as the spin-up run. After that, the model was integrated from 1 January
1997 until 30 June 2009 with $6 \mathrm{~h}$ reanalyses from the U.S. National Oceanic and Atmospheric Administration/National Centers for Environmental Prediction/National Center for Atmospheric Research (NOAA/NCEP/NCAR) (available at http://ncdc.noaa.gov) (Kalnay et al., 1996). NCEP post-processing of the reanalyses converted the data from the spectral resolution T62 and 28 vertical levels to $1^{\circ}$ latitude-longitude grid, and from sigma levels to 17 mandatory pressure levels. This interpolated data with $1^{\circ}$ resolution was employed to force HYCOM. 
Similar runs with the $1 / 12^{\circ}$ grid nested in the $1 / 4^{\circ}$ grid were performed, but it grid was initialized with the $1 / 4^{\circ}$ output taken from the result of year 31 of the spin-up run. After that, a spin-up run of 10 years with COADS was followed by a 5.5 -year integration with the interpolated $1^{\circ}$ reanalysis forcing, from 1 January 2003 until 30 June 2009. In all runs, HYCOM was forced with wind stress, precipitation, surface air temperature, surface specific humidity - transformed into surface mixing ratio - and net longwave and shortwave fluxes. Rivers were imposed by a parameterization based on precipitation minus evaporation from climatological monthly mean data.

\section{The optimal interpolation scheme}

The 0 l scheme is based on the equations

$$
\begin{aligned}
X_{a} & =X+K(Y-H X) \\
K & =B H^{\prime}\left(H B H^{\prime}+R\right)^{-1},
\end{aligned}
$$

where $X_{a}$ represents the SSHA analysis, $X$ the model background SSHA or first guess or prior state - given by the model SSH minus model SSH mean considering the 10 year run,$- K$ is the gain matrix, $Y$ is the observational vector, $H$ is the observation operator, $\mathrm{B}$ is model error covariance matrix and $R$ is the observation error covariance matrix. $R$ was assumed as a diagonal matrix with constant squared errors equal to $(0.02 \mathrm{~m})^{2}$. $B$ was parameterized as a function of the model variance from the 20032009 forced run and the inverse of the squared distance between the analysis point and the observational point. The model error covariance between points $i$ and $j$ is given by the formula

$$
B(i, j)=\sigma_{i}^{2} \exp \left(-r_{i j}^{2} / L^{2}\right),
$$

where $\sigma_{i}^{2}$ is the variance of the model at the grid point $i$ taken as an estimate of the model squared error, $r_{i j}^{2}=\left(x_{i}-x_{j}\right)^{2}+$ $\left(y_{i}-y_{j}\right)^{2}$ is the horizontal distance between points $i$ and $j$, and $L$ is a decorrelation factor equal to $170 \mathrm{~km}$, used in Mellor \& Ezer (1991) and Ezer \& Mellor (1997) for the North Atlantic. Therefore, the method employed here was only a statistical interpolation scheme, which can be improved. For instance, the decorrelation factor could be chosen based on specific correlations of the model variables with horizontal variability over the domain of interest. Also, $B$ could be estimated by ensemble forecasts. These improvements are being pursued and the results will be presented in future works.

The mean of the along-track SSHA and the mean of the model SSHA interpolated to the along-track observational points did not coincide. A difference of about $25 \mathrm{~cm}$ was observed. The causes of this difference are under investigation, but they are probably caused by the different references employed to calculate them. The along-track observed SSHA is calculated by the difference between the instantaneous SSH observed by the satellite and the observed SSH mean over about 7 years of observations. The observed SSH is taken with respect to a geoid that is today not completely known. The model SSHA is calculated by the difference of the instantaneous SSH produced by the model and the model SSH mean taken from the model free run. Since the model SSH mean depends of the forcing, resolution, parameterizations, bathymetry and period of the integration, it is expected that the model SSH mean does not match the observed SSH mean. Therefore, their anomalies would not match as well and this would lead to a bias.

In order to capture the location and magnitude of the observed troughs and ridges of SSHA and smoothly pass this information to the model in a manner to avoid abrupt changes in the model state, an adjustment of the observed data is imposed. First, the model SSHA is interpolated to the observed along-track SSHA location. Then, the average along the satellite track is taken for the observations and for the model and their difference is calculated and subtracted from the observational data to match the model mean. Therefore, the adjusted observational data and the model have the same mean along each track.

Figure 3 shows an example of the along-track raw data, the model SSHA and the adjusted along-track raw data. It shows the observed SSHA is about $25 \mathrm{~cm}$ higher than the model SSHA along the satellite track.

The adjusted observational data is assimilated by the 0 l scheme imposing an analysis increment and correction of the model only with local SSHA features. An example of the impact of the assimilation in the background SSHA can be seen by the pattern of the analysis increment with positive and negative anomalies organized in a strip around the satellite track shown in Figure 4. In this example, the data window was only one day.

Once having the SSHA analysis, it was added to the model SSH mean and the reconstructed SSH is obtained. The latter serves as input to the C\&H scheme to rearrange the background model SSH and to reorganize the model layer thicknesses to match the given SSH. To correct the model SSH, the C\&H scheme takes low (high) density water parcel from the upper (bottom) layer and inserts it as high (low) density water in the bottom (upper) layer to decrease (increase) SSH. No change in the mixed layer temperature was applied during this procedure, so that it is up to the model dynamics along the integration to produce changes in the temperature mixed layer. 


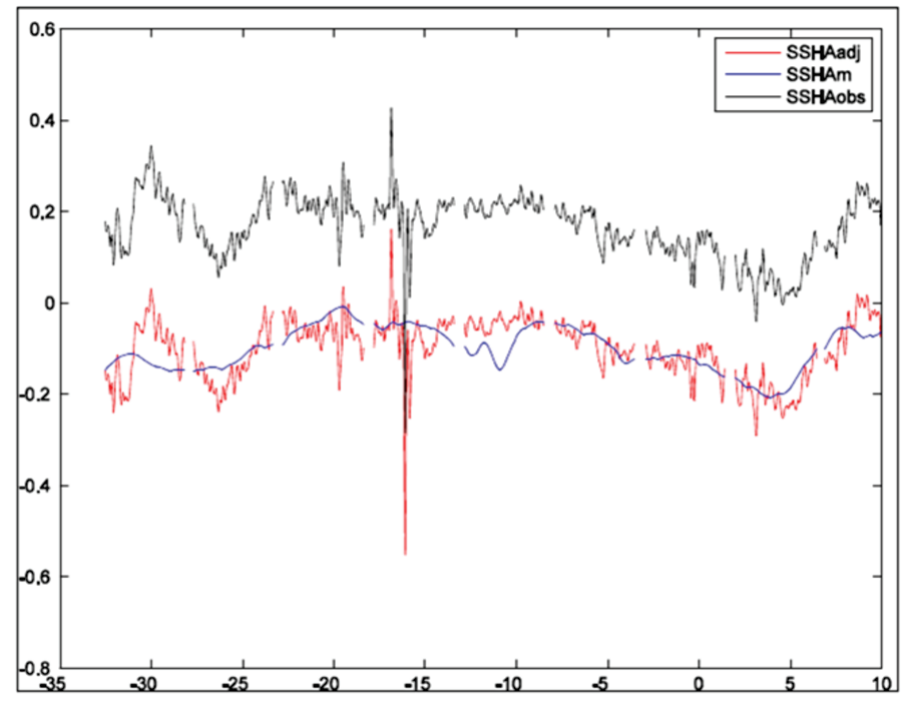

Figure 3 - Jason-1 along-track SSHA unfiltered data (black), interpolated model SSHA to the track (blue) and adjusted unfiltered data (red) from $35^{\circ} \mathrm{S}$ until $10^{\circ} \mathrm{N}$. Unit is $\mathrm{m}$.

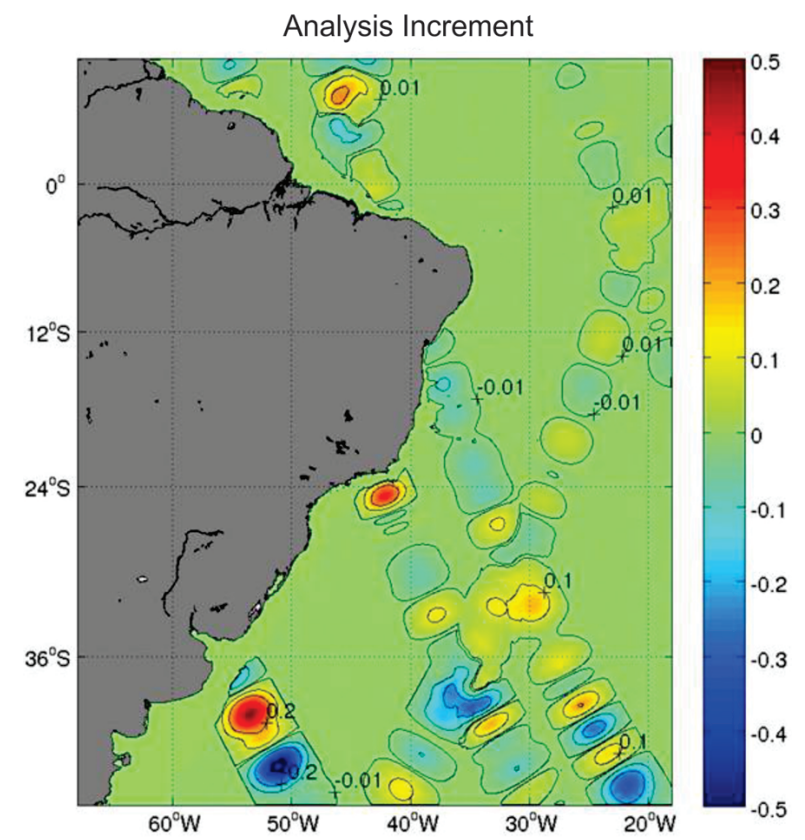

Figure 4 - Illustration of the first SSHA analysis increment produced by a single assimilation step that considered Jason-1 and Jason-2 along-track SSHA data in one-day window. Unit is $\mathrm{m}$.

\section{The numerical experiments}

Two integrations were performed from 1 July until 31 December 2009 taking the 6-hr NCEP/NCAR reanalysis atmospheric forcing and model configuration used in the run from January 2003 to June 2009. In the first run, the control run, the model was integrated without assimilation. In the second run, the assimilation run, the model assimilated the filtered and adjusted SSHA along- track data from Jason-1 and Jason-2 each 3 days. A time-window of 7 days for the SSHA data was employed in each realization of assimilation. After assimilation, the C\&H scheme was applied and the new model stated was used as initial condition for the simulation and for the next assimilation cycle.

\section{RESULTS AND DISCUSSION}

The results of the integration show that in about three months the model is able to reconstruct its large-scale altimetry pattern. Figure 5 shows anomalies of SSHA with respect to area averaged SSHA from the control run, the assimilation run and the HYCOM+NCODA analysis for July 2, September 30 and December 31,2009 , the last day of the experiment. In July 2, after a single assimilation step, the differences between the control and the assimilation runs are almost none and the HYCOM+NCODA shows a much smaller region with positive anomalies above $20 \mathrm{~cm}$, and a much larger region with negative anomalies. In September 30, the HYCOM+NCODA analysis shows a substantial reduction of the positive anomalies off the S-SE region of Brazil between $30^{\circ} \mathrm{W}-45^{\circ} \mathrm{W}$ and $18^{\circ} \mathrm{S}-27^{\circ} \mathrm{S}$. The control run still presents peaks with $30 \mathrm{~cm}$ in this region, but the assimilation run does not, showing it was able to reduce the magnitude of these anomalies and produce a better agreement with the global analysis. Also, positive anomalies in the northern part of the domain, which are in the HYCOM+NCODA analysis, were not captured by the control run, but were reproduced in the assimilation run. In the end of the experiment, several dif- 

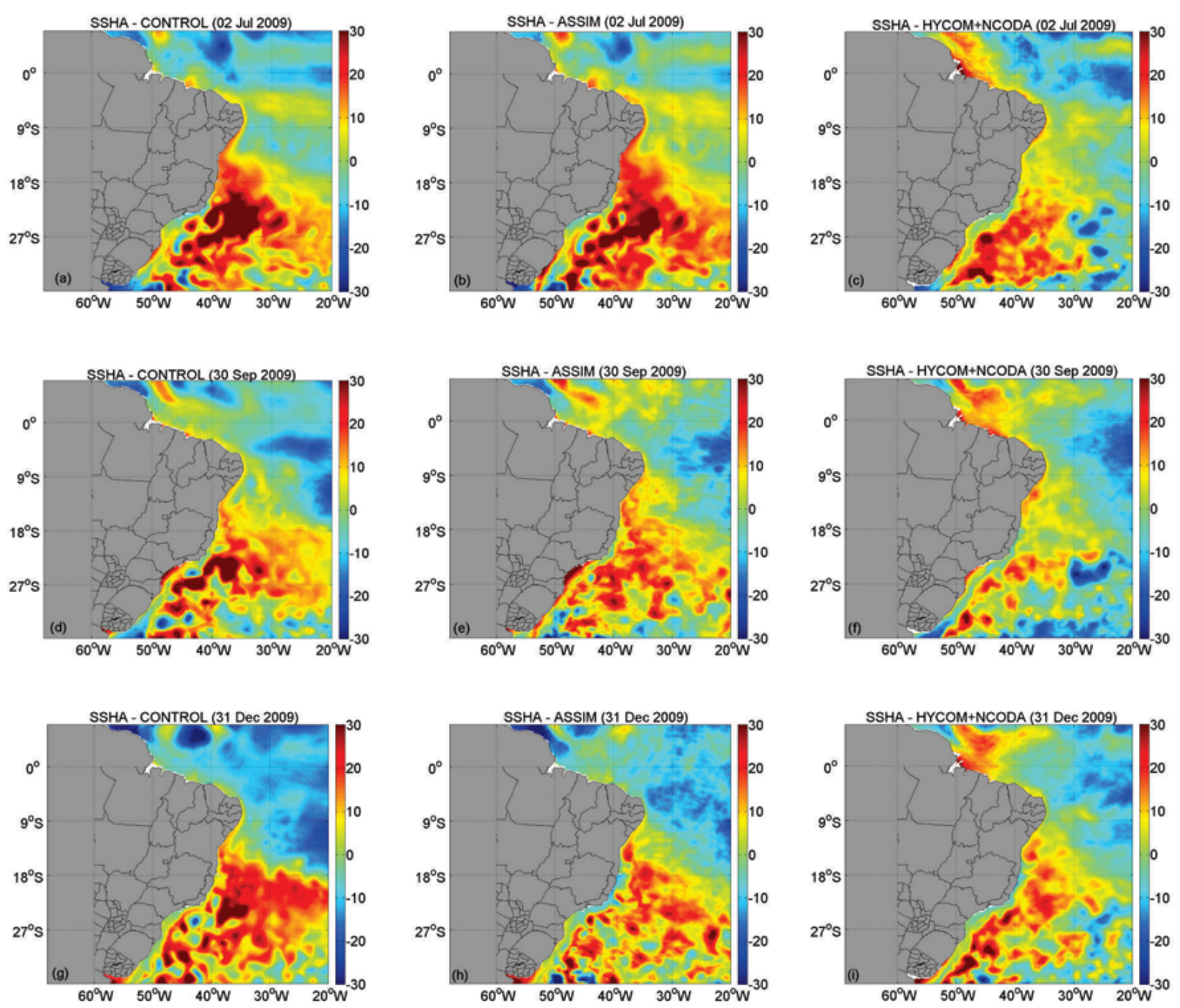

Figure 5 - SSHA (cm) anomalies with respect to area average on July 2 (first row), 30 September 30 (second row) and December 31, 2009 (third row) produced by the control run (first column), the assimilation run (second column) and the HYCOM+NCODA analysis (third column).

ferences are observed between the control and the assimilation run. The control run has much larger positive anomalies and smaller negative anomalies than the assimilation run, and the latter was closer to the HYCOM+NCODA analysis. However, there are also differences between the assimilation run and the HYCOM+NCODA analysis. Despite the latter be a reference, one cannot expect the assimilation run to produce the same altimetry pattern as the global analysis, because the latter used a variety of observations in a multivariate assimilation scheme and it was integrated with different vertical resolution and different atmospheric forcing. The assimilation of SSHA in combination with the C\&H scheme should not be in general as effective as multivariate assimilation system, because it does not include other oceanic variables and it does not pass the information of the innovation directly to all model primitive variables, but only to few model layer thicknesses.

In order to verify the results of the assimilation run against observed altimetry data, the control run and the assimilation run were compared to the AVISO global SSHA data with $1 / 3^{\circ}$ resolution. To filter out model biases and discrepancies between the reference level over which the observed SSHA and the model SSHA are evaluated, the area average over the METAREA $V$ of the observational altimetry data and of the model runs were subtract from their respective fields. The resulting anomaly was used to calculate the centered RMSE, shown in Figure 6, after the observational data be interpolated to the model grid. The 

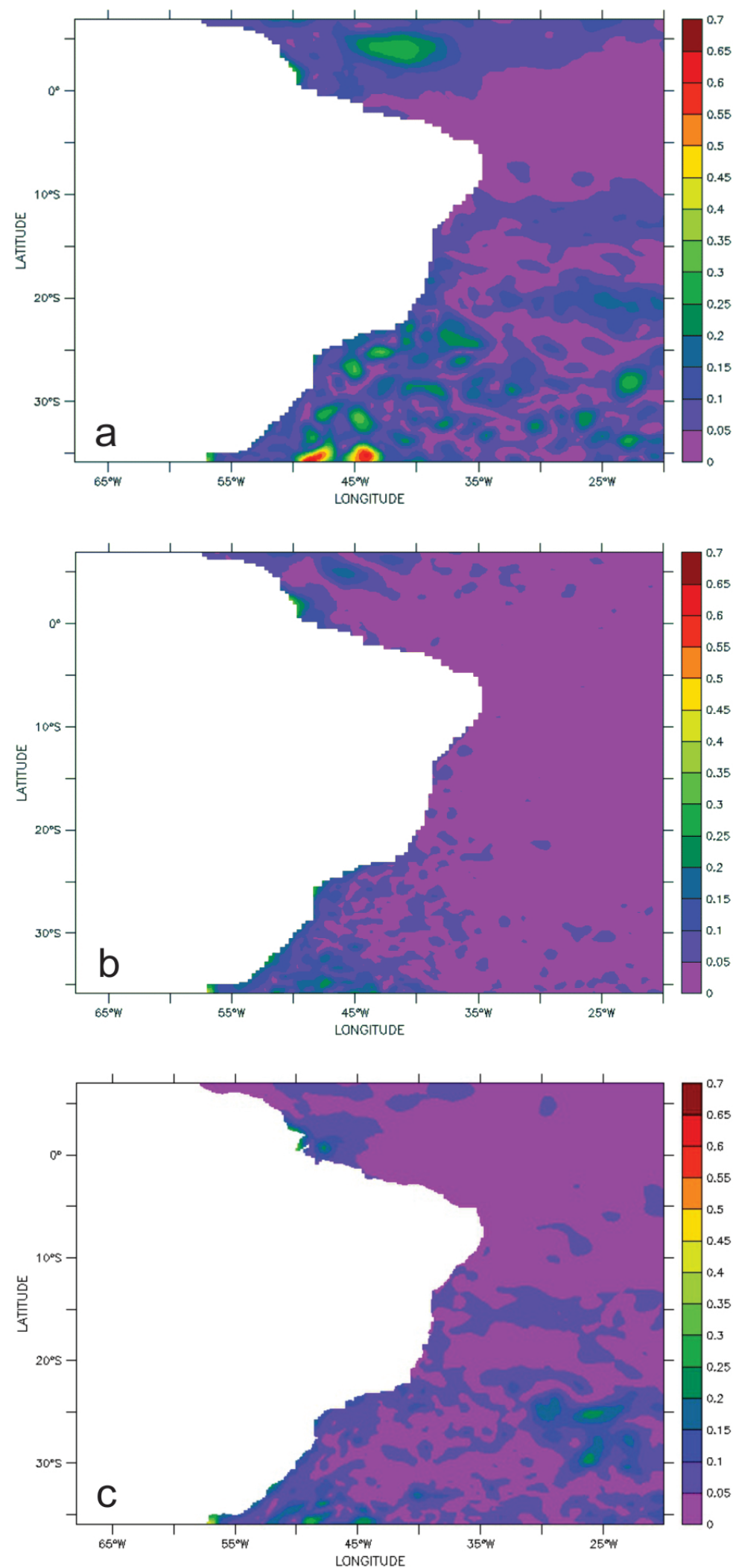

Figure 6 - Centered RMSE of the SSHA anomaly (m) with respect to AVISO for December 2009 for (a) the control run; (b) the assimilation run and (c) the HYCOM+NCODA analysis. 
control run centered RSME of the anomaly (Fig. 6a) reaches a maximum of $0.7 \mathrm{~m}$ in the southern border of the METAREA $\mathrm{V}$ in a well-known region for its intense dynamics due to the BrazilMalvinas Confluence. In the equatorial region and in the subtropics the errors reach $0.4 \mathrm{~m}$. The errors of the assimilation run are close to zero in great part of the domain and the largest errors of about $0.2 \mathrm{~m}$ are localized in the very south of the METAREA $V$ and in the mouth of the Amazon River. Therefore, the comparison with observational data also shows improvements obtained by the assimilation of along-track SSHA in conjunction with the $\mathrm{C} \& \mathrm{H}$ scheme. Figure 6 also presents the results of the HYCOM+NCODA analysis for the same period. The errors of this analysis with respect to the AVISO gridded data is similar to the one produced in the assimilation run with largest values in the Brazil-Malvinas Confluence and in the mouth of the Amazon river. However, there are also errors of about $0.2 \mathrm{~m}$ in a region between approximately $20^{\circ} \mathrm{W}-30^{\circ} \mathrm{W}, 22^{\circ} \mathrm{S}-32^{\circ} \mathrm{S}$. This region is also dominated by relatively high SSHA variability and by the presence of Argo profilers. Temperature and salinity profiles from Argo are also assimilated by HYCOM+NCODA and should produce an impact in the model altimetry. Since the only constrain imposed in the assimilation run of the present work was SSHA, this particular field had a slightly better representation than the HYCOM+NCODA analysis in December 2009.

Model altimetry is associated with in other model variables, particularly, the currents, which were very much altered by assimilation of SSHA and the C\&H scheme. Important modifications were observed in the region of the Bifurcation of the South Equatorial Current (BiSEC). Taking the monthly mean for December 2009, the control run produced the BiSEC around of $17^{\circ} \mathrm{S}$, while the assimilation run and the HYCOM+NCODA positioned it around $12^{\circ} \mathrm{S}$ (Fig. 7). This position is in better agreement with observations. Rodrigues et al. (2006) observed it in $13^{\circ} \mathrm{S}$ during November. Silveira et al. (2000) and Stramma et al. (1990) observed it around $10^{\circ} \mathrm{S}$, and Soutelino (2008) in $9^{\circ} \mathrm{S}$ and $12^{\circ} \mathrm{S}$ for the circulation at $20 \mathrm{~m}$ and $200 \mathrm{~m}$ depth, respectively.

Substantial modifications in the currents were also verified in other regions. For instance, the monthly mean meridional velocity for December 2009 at $22^{\circ} \mathrm{S}$ contains a clear signature of the southward Brazil Current (BC) at the surface and of the northward Intermediate Western Boundary Current (IWBC) close to the Brazilian shore, as shown in Figure 8. However, the control run produced a relatively weak and shallow $\mathrm{BC}$ over the Brazilian continental shelf/slope with minimum of $-0.2 \mathrm{~m} / \mathrm{s}$, a stronger southward current in the deep ocean around $38.5^{\circ} \mathrm{W}$ with minimum of $-0.4 \mathrm{~m} / \mathrm{s}$ and a relatively strong IWBC at the continental slope with maximum of $0.4 \mathrm{~m} / \mathrm{s}$. The assimilation run produced a pattern much more close to the HYCOM+NCODA analysis and to observations. It intensified the $\mathrm{BC}$, reduced the magnitude of the southward flow around $38^{\circ} \mathrm{W}$ and reduced the magnitude of the IWBC. Also, a relatively weak southward flow is observed in the assimilation run and in the HYCOM+NCODA in contrast to a stronger flow in the control run to the east of the northward flow over the slope. Observations by Silveira et al. (2008) with 10 current meters distributed in the depths of 50 m, 100 m, 150 m, 250 m, 350 m, 450 m, 550 m, 750 m, $900 \mathrm{~m}$ and $1050 \mathrm{~m}$ located at $22.7^{\circ} \mathrm{S}, 40.2^{\circ} \mathrm{W}$ for 1 year showed the meridional velocity of the $\mathrm{BC}$ at $50 \mathrm{~m}$ was about $-0.4 \mathrm{~m} / \mathrm{s}$ and that the change from southward to northward occurred at the $400 \mathrm{~m}$ depth. Between 800 and $1050 \mathrm{~m}$, the IWBC was observed by Silveira et al. (2008) with $0.2 \mathrm{~m} / \mathrm{s}$. This value is very close to observations by Schmid et al. (1995), who found a core of $0.3 \mathrm{~m} / \mathrm{s}$ between 800 and $1000 \mathrm{~m}$ depth. Good agreement between the assimilation run and the HYCOM+NCODA currents was also observed in other cross sections (not shown).

The southward transport by the BC from the shore until $39^{\circ} \mathrm{W}$ at $22^{\circ} \mathrm{S}$ produced by the control run, the assimilation run and the HYCOM+NCODA in December 2009 were $1.3 \mathrm{~Sv}$, 4.1 Sv and 4.8 Sv, respectively. According to Evans \& Signorini (1985) and Silveira et al. (2004), the BC transport in this region is given by $6 \mathrm{~Sv}$ and $5.6 \pm 1.4 \mathrm{~Sv}$, respectively. The northward transport by the IWBC in the same region were $7.89 \mathrm{~Sv}, 4.81 \mathrm{~Sv}$ and $1.92 \mathrm{~Sv}$ for the control run, the assimilation run and the HYCOM+NCODA, respectively. According to Silveira et al. (2004) the observed transport by IWBC was $3.6 \pm 0.8 \mathrm{~Sv}$. Therefore, the assimilation run produced a positive impact in the currents and transport in this region not only in the surface but also in the subsurface. Positive impacts were also verified in other regions (not shown).

Temperature $(T)$ and salinity $(S)$ were not assimilated in the present experiments, but modifications in the model altimetry and layer thicknesses should also influence the thermohaline structure. The model runs were compared with vertical profiles of $T$ and $S$ from Argo. Data were limited in METAREA V, so that the maximum number of Argo profiles in a single day during the experiment was 9 , and in several days there were no available observations. Anyway, RMSE for $T$ and $S$ for the model runs were calculated because these are objective information about the model quality. The model results were horizontally interpolated to the position of the observations and RMSEs were calculated for each day among all profiles at the WOA standard $z$-levels until $2000 \mathrm{~m}$. Maximum errors were verified between 

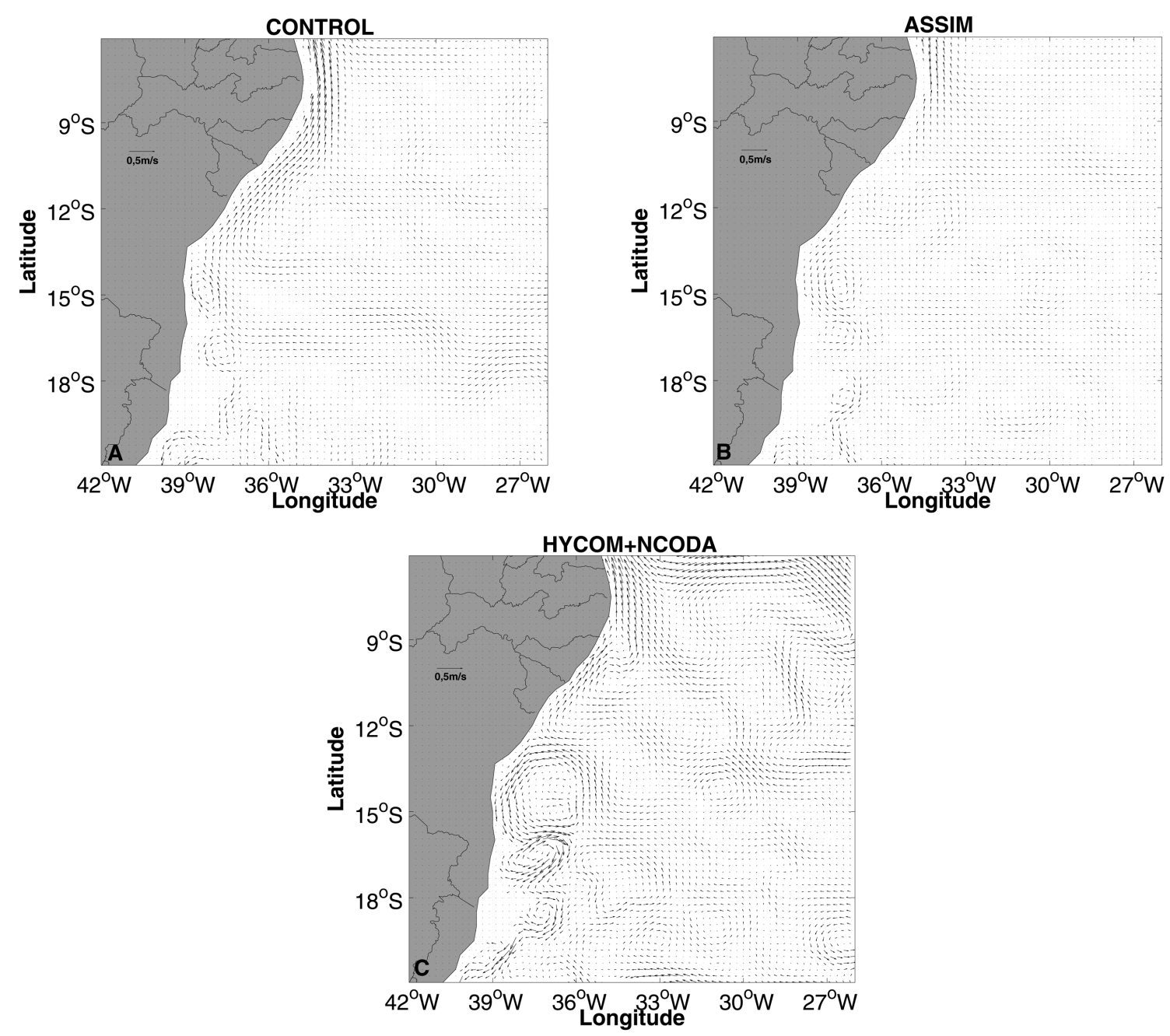

Figure 7 - Monthly mean horizontal velocity (m/s) for December 2009 at $75 \mathrm{~m}$ depth for (a) the control run; (b) the assimilation run; and (c) the HYCOM+NCODA.

$70 \mathrm{~m}$ and $150 \mathrm{~m}$ depth for $T\left(6^{\circ} \mathrm{C}\right)$ and between the surface and $200 \mathrm{~m}$ for $S$ (1 psu) for both the control and the assimilation runs.

The vertically integrated monthly mean RMSE for $T$ and $S$, and their standard deviation (STD) from surface until $150 \mathrm{~m}$ for $T$ and from surface until $200 \mathrm{~m}$ for $S$ were calculated. From July until October 2009, the RMSEs and STDs for $T$ in the assimilation run were smaller than in the control run, as seen in Table 1, showing an improvement of the temperature structure with assimilation and C\&H. In November, the RMSE and the STD in the assimilation run were greater than in the control run, and in December they were about the same. The RMSEs and STDs for $S$ were about the same in the control and assimilation runs. The results show that the impact of SSHA assimilation and C\&H in $T$ and $S$ is not al- ways positive, but in general $T$ was adjusted in the direction of the observations.

To illustrate the impact of the assimilation and C\&H strategy in the simulation of water masses in the equatorial and subtropical West Atlantic, two $T-S$ diagrams with information from the control run, the assimilation run, HYCOM+NCODA and Argo are shown in Figure 9. Two specific days were evaluated using model results from surface until $3000 \mathrm{~m}$ and data from surface until $2000 \mathrm{~m}$. In the equatorial region, Figure 9a, the assimilation run produced slightly better temperature in the surface with respect to the control run. The vertical profile of temperature showed a much better representation of the mixed layer temperature and thermocline in this point (not shown). However, surface salinity in the control and in the assimilation runs were 

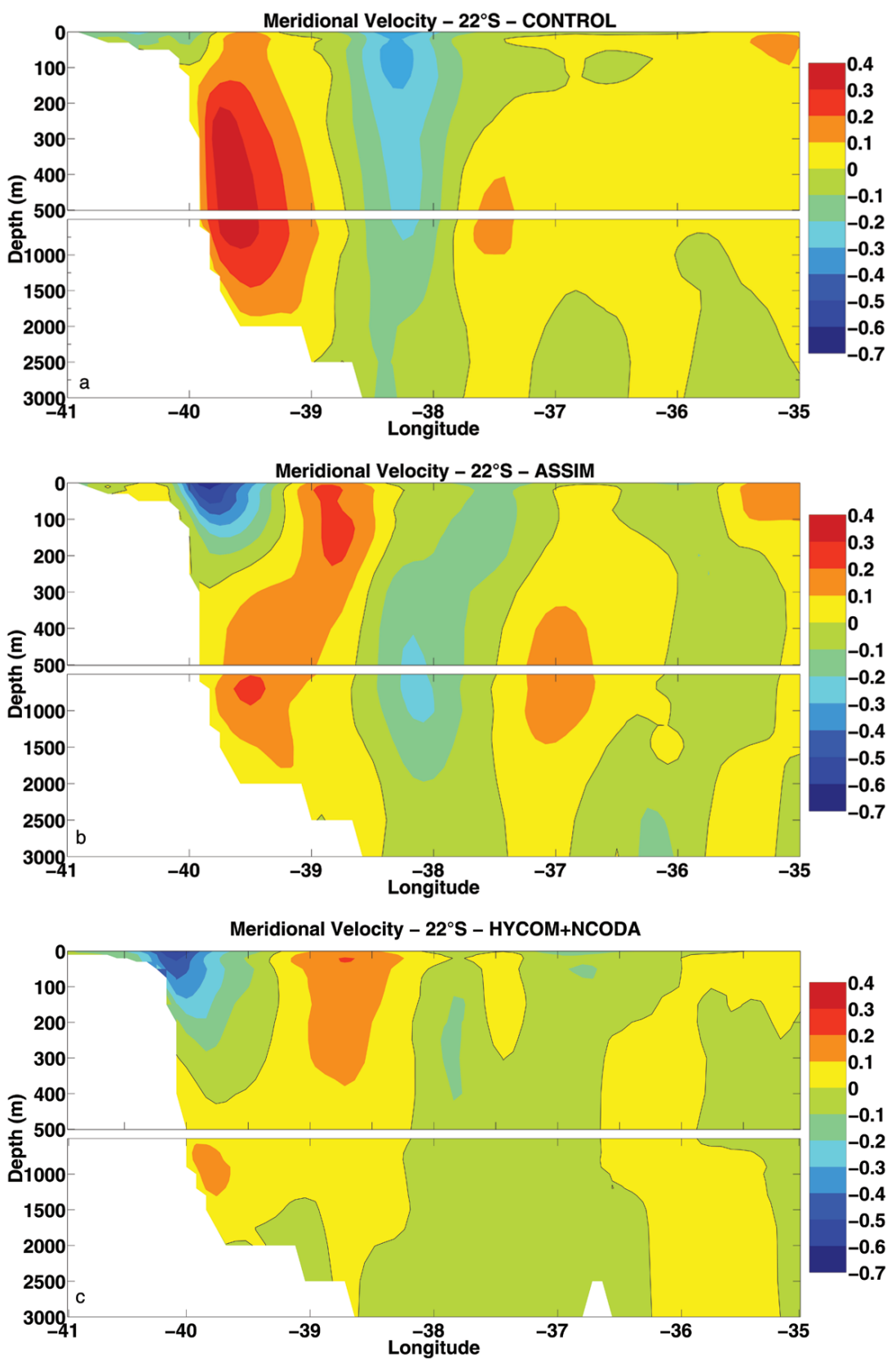

Figure 8 - Vertical cross section of the monthly mean meridional velocity $(\mathrm{m} / \mathrm{s})$ for December 2009 at $22^{\circ} \mathrm{S}$ according to (a) the control run; (b) the assimilation run; and (c) the HYCOM+NCODA.

smaller than Argo data, so that Tropical Water (TW) and South Atlantic Central Water (SACW) were not well represented. In the deep ocean, the control and the assimilation runs did not accurately represent the Antarctic Intermediate Water (AIW), because salinity was almost constant and quite different from data and the HYCOM+NCODA analysis. The control and assimilation runs produced similar North Atlantic Deep Water (NADW) to the HYCOM+NCODA analysis. The differences obtained in the Southwest Atlantic by the control and the assimilation runs were larger than in the equatorial region. In the surface, the control and the assimilation runs were much less saline than the Argo data causing a large discrepancy in the TW and in the SACW. In the deep ocean, the control and assimilation runs are close to Argo data and the HYCOM+NCODA analysis. 
Table 1 - Monthly mean of the vertically averaged potential temperature (T) and salinity (S) RMSE and its standard deviation - with respect to the time mean - from the surface to $150 \mathrm{~m}$ depth with respect to the Argo temperature data for the control run and the assimilation run along the experiment period. Units are $\left({ }^{\circ} \mathrm{C}\right.$ ) and (psu).

\begin{tabular}{|c|c|c|c|c|c|c|c|c|}
\hline & & & JUL & AUG & SEP & OCT & NOV & DEC \\
\hline \multirow{3}{*}{ CONTROL } & \multirow{2}{*}{$\mathrm{T}$} & RMSE & 2,15 & 2,36 & 1,99 & 1,96 & 1,80 & 1,99 \\
\cline { 2 - 9 } & & STD & 0,94 & 1,01 & 0,81 & 0,91 & 0,92 & 0,93 \\
\cline { 2 - 9 } & \multirow{2}{*}{$\mathrm{S}$} & RMSE & 0,48 & 0,46 & 0,46 & 0,44 & 0,43 & 0,43 \\
\cline { 3 - 8 } & & STD & 0,17 & 0,17 & 0,17 & 0,15 & 0,14 & 0,15 \\
\hline \multirow{3}{*}{ ASSIM } & \multirow{2}{*}{$\mathrm{T}$} & RMSE & 1,91 & 1,78 & 1,77 & 1,83 & 1,87 & 1,92 \\
\cline { 3 - 9 } & & STD & 0,92 & 0,78 & 0,69 & 0,84 & 0,95 & 0,96 \\
\cline { 2 - 8 } & \multirow{2}{*}{$\mathrm{S}$} & RMSE & 0,50 & 0,47 & 0,47 & 0,45 & 0,49 & 0,47 \\
\cline { 3 - 8 } & & STD & 0,18 & 0,18 & 0,18 & 0,18 & 0,19 & 0,17 \\
\hline
\end{tabular}
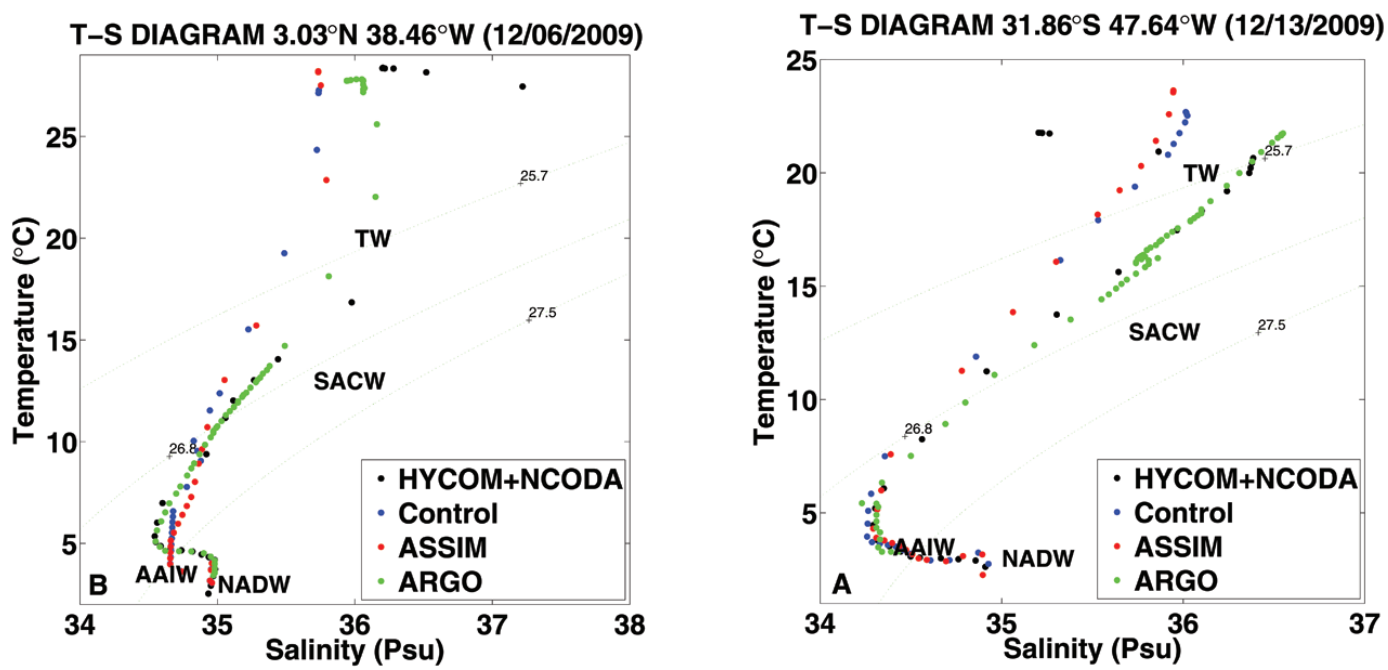

Figure 9 - Temperature-Salinity diagram according to the control run (blue), assimilation run (red), Argo data (green) and HYCOM+NCODA analysis (black) for the positions. (a) $3.03^{\circ} \mathrm{N}, 38.46^{\circ} \mathrm{W}$ on December 6, 2009; and (b) $31.86^{\circ} \mathrm{S}, 47.64^{\circ} \mathrm{W}$ on December 13, 2009.

\section{CONCLUSION}

Assimilation of along-track sea surface height (SSH) anomalies (SSHA) satellite data into HYCOM followed by the application of the Cooper \& Haines (1996) scheme (C\&H) was realized in a 6-month experiment in the Atlantic Ocean METAREA V. The present work proposes a new strategy to overcome wellknown biases between model and observed SSHA that produces an analysis with focus on the major differences in the meso-scale patterns between model and observation. The scheme respects the model SSHA mean and adjusts the along-track data towards the model mean. The approach employed here produced substantial improvements in the model SSHA with respect to results from a control run without assimilation. Maximum errors were reduced from $0.7 \mathrm{~m}$ to $0.2 \mathrm{~m}$ in small regions of the domain. These results were slightly better than the SSHA HYCOM+NCODA ana- lysis. The reconstructed SSH caused modifications in the surface and subsurface currents. Particularly, the Bifurcation of the South Equatorial Current, the Brazil Current and the Intermediate Western Boundary Current in the assimilation run were more accurate when compared to observational data and climatological studies (e.g., Evans \& Signorini, 1985; Silveira et al., 2008). Results from the global analysis of the US Naval Oceanographic Office HYCOM+NCODA system were also used to corroborate the observed improvements in SSH and currents.

However, the impact of SSHA assimilation and the C\&H scheme in the model thermohaline structure was not always positive, since temperature and salinity errors of the assimilation run with respect to Argo data were not always smaller than errors of the control run. The assimilation of SSHA can be improved, for instance, by considering spatial dependence of the decorrelation factor used in the parameterization of the background error covari- 
ance as in Lima \& Tanajura (2013) in this issue. Nevertheless, to accurately constrain the ocean tri-dimensional state, a full multivariate data assimilation system should be pursued. The present work should be seen as a first step in this direction.

This work demonstrated that an efficient scheme to assimilate along-track satellite data was successfully implemented into HYCOM and that it can be used for operational purposes under REMO while a multivariate data assimilation system is under development.

\section{ACKNOWLEDGMENTS}

This work was supported by PETROBRAS and the Brazilian oil regulatory agency ANP (Agência Nacional de Petróleo, Gás Natural e Biocombustíveis), within the special participation research project Oceanographic Modeling and Observation Network (REMO). The authors would like to thank Mr. Jonatas Castro Einsiedler for his support in the model integration.

\section{REFERENCES}

BLECK R. 2002. An oceanic general circulation model framed in hybrid isopycnic-Cartesian coordinates. Ocean Modell., 4: 55-88.

BLECK R. 2006. On the use of hybrid vertical coordinates in ocean circulation modeling. In: Ocean Weather Forecasting. An Integrated View of Oceanography, CHASSIGNET EP \& VERRON J (Eds.), Springer, 109126.

BLECK R \& BOUDRA DB. 1981. Initial testing of a numerical ocean circulation model using a hybrid quasi isopycnal vertical coordinate. J. Phys. Oceanogr., 11: 755-770.

BLECK R \& BENJAMIN SG. 1993. Regional weather prediction with a model combining terrain-following and isentropic coordinates. Part I: Model description. Mon. Wea. Rev., 121: 1770-1785.

CHASSIGNET EP, HURLBURT HE, METZGER EJ, SMEDSTAD OM; CUMMINGS J; HALLIWELL GR, BLECK R, BARAILLE R, WALLCRAFT AJ, LOZANO C \& OTHERS. 2009. US GODAE. Global ocean prediction with the HYbrid Coordinate Ocean Model (HYCOM). Oceanography, 22: 64-75.

COOPER M \& HAINES K. 1996. Altimetric assimilation with water property conservation. J. Geosphys. Res., 101(C1): 1059-1077.

CUMMINGS J, BERTINO L, BRASSEUR P, FUKUMORI I, KAMACHI M, MARTIN M, MOGENSEN K, OKE P, TESTUT C, VERRON J \& WEAVER A. 2009. Ocean Data Assimilation Systems for GODAE. Oceanography, 22: 96-109.

DALEY R. 1991. Atmospheric data analysis. Cambridge University Press, $457 \mathrm{pp}$.

DOMBROWSKY E, BERTINO L, BRASSINGTON GB, CHASSIGNET EP, DAVIDSON F, HURLBURT HE, KAMACHI M, LEE T, MARTIN MJ, MEI S
\& TONANI K. 2009. GODAE systems in operation. Oceanography, 22: 80-95.

EVANS DL \& SIGNORINI SR. 1985. Vertical structure of the Brazil Current. Nature, 315: 48-50.

EZER T \& MELLOR GL. 1997. Data Assimilation Experiments in the Gulf Stream Region: How useful are Satellite-Derived Surface Data for nowcasting the sub-surface fields? J. Atmosph. Oceanogr., 14, 1379-1391.

GCOS-92. 2004. Implementation plan for the Global Observing System for climate in support of the UNFCCC. United Nations Environment Programme/International Council for Science. World Meteorological Organization/TD No. 1219, 23 pp.

KALNAY E. 2003. Atmospheric modeling, data assimilation and predictability. Cambridge University Press, $341 \mathrm{pp}$.

KALNAY E \& CO-AUTHORS. 1996. The NCEP/NCAR 40-year reanalysis project. Bull. Amer. Meteorol. Soc., 77: 437-472.

MELLOR GL \& EZER T. 1991. A Gulf Stream model and an altimetry assimilation scheme. J. Geosphys. Res., 96(C5): 8779-8795.

OKE P, BALMASEDA M, BENKIRAN M, CUMMINGS J, DOMBROSWKY E, FUJII Y, GUINEHUT S, LARNICOL G, LE TRAON PY, \& MARTIN M. 2009. Observing Systems Evaluations Using GODAE Systems. Oceanography, 22: 144-153.

RODRIGUES RR, ROTHSTEIN LM \& WINBUSH M. 2006. Seasonal variability of the South Equatorial Current bifurcation in the Atlantic Ocean: A Numerical Study. J. Phys. Oceanogr., 37: 16-30.

SCHMID CH, SCHAFER H, PODESTA G \& ZENK W. 1995. The Vitoria eddy and its relation to the Brazil Current. J. Phys. Oceanogr., 25: 25322546.

SILVEIRA ICA, SCHMIDT ACK, CAMPOS E, GODOI S \& IKEDA Y. 2000. A Corrente do Brasil ao largo da costa leste brasileira. Rev. Bras. Oceanogr., 48: 171-183.

SILVEIRA, ICA, CALADO L, CASTRO B, CIRANO M, LIMA JA \& MASCARENHAS AS. 2004. On the baroclinic structure of the Brazil Current - Intermediate Western Boundary Current system at $22^{\circ} \mathrm{S}-23^{\circ} \mathrm{S}$. Geophys. Res. Lett. 31: 1-5.

SILVEIRA, ICA, LIMA JA, SCHMIDT ACK, CECCOPIERI W, SARTORI A, FRANCISCO C, \& FONTES R. 2008. Is the meander growth in the Brazil Current system off southeast Brazil due to baroclinic instability? Dyn. Atmos. Ocean, doi: 101016. 1-21.

SOUTELINO RG. 2008. A origem da Corrente do Brasil. Dissertação de Mestrado. Instituto Oceanográfico USP, SP, Brasil, 101 pp.

STRAMMA L, IKEDA Y \& PETERSON RG. 1990. Geostrophic transport in the Brazil Current region. Deep-Sea Res., 37(1A): 1875-1886.

TANAJURA CAS \& BELYAEV K. 2009. A sequential data assimilation method based on the properties of a diffusion-type process. Appl. Math. Model., 33: 2165-2174. 


\section{NOTES ABOUT THE AUTHORS}

Clemente Augusto Souza Tanajura is mechanical-nuclear engineer with Ph.D. in Meteorology by the Center for Ocean-Land-Atmosphere Studies (COLA), University of Maryland, College Park, US. Was Associate Researcher for the Brazilian National Laboratory for Scientific Computing (LNCC) for 18 years and currently is a Professor for the Universidade Federal da Bahia. Was the scientific-technological coordinator of the Oceanographic Modeling and Observation Network (REMO) from December 2008 until March 2013 and he is a member of the GODAE OceanView Science Team. Works with data assimilation, ocean and atmosphere modeling, short-range weather and ocean predictability and climate studies.

Filipe Bitencourt Costa is an oceanographer by the Universidade Federal da Bahia (UFBA) and is currently a graduate student of the Graduate Program in Geophysics, UFBA working with ocean modeling and data assimilation.

Renato Ramos da Silva is a physicist with Ph.D. in Meteorology by the Duke University. Worked as a researcher on regional climate modeling at FUNCEME, lowa State University, Rutgers University, Universidade Federal do Pará (UFPA), and Universidade Federal da Bahia (UFBA). Currently is a Professor at Universidade Federal de Santa Catarina (UFSC). Works with climate modeling, numerical weather prediction, sea-air interactions and climate change.

Giovanni Abdelnur Ruggiero is an oceanographer with M.Sc. in Computational Modeling by the Universidade Federal do Rio Grande (FURG) by 2010. Has experience in physical oceanography, particularly on ocean modeling, ocean forecasting systems and data assimilation. Currently is a PhD student in applied mathematics at University of Nice-Sophia Antipolis. Works with ocean modeling and data assimilation methods.

Victor Bastos Daher is an oceanographer with M.Sc. in Physical Oceanography by the Universidade de São Paulo (USP). Has experience in observational oceanography, particularly on satellite oceanography with emphasis on altimetry. 